\begin{tabular}{|c|c|c|}
\hline Beitr. Ent. & Keltern & ISSN 0005-805X \\
\hline $\mathbf{5 1}(2001) 1$ & S. $155-160$ & 14.09 .2001 \\
\hline
\end{tabular}

\title{
First record of Cordyla MEIGEN and Monoclona MiK from the Oriental region
}

\section{(Diptera: Mycetophilidae)}

With 2 figures

\section{JAN ŠEVČ́́K}

\section{Summary}

Cordyla orientalis sp. $\mathrm{n}$. and Monoclona laosiluatica sp. n. are described from the Bolaven Plateau in southern Laos. This is the first record of these principally Holarctic genera from the Oriental region.

The new species of Cordyla belongs to the species group with yellowish coloration, 12 flagellomeres and long stem of Cu-fork, and is thus most closely related to the Palaearctic Cordyla flaviceps (STAEGER, 1840) and C. fasciata MEIGEN, 1830. The new species of Monoclona belongs to the species group with ventrally separated gonocoxites and is closely related to Monoclona silvatica ZAITZEV, 1983, M. onientalis ZAITZEV, 1983 and $M$. ruflatera (WALKER, 1837).

\section{Zusammenfassung}

Cordyla orientalis sp. $\mathrm{n}$. und Monoclona laosilvatica $\mathrm{sp} . \mathrm{n}$. werden aus Süd-Laos vom Bolaven-Plateau beschrieben. Für die orientalische Region sind das die ersten Nachweise aus den sonst holarktisch verbreiteten Gattungen. Die neue Cordyla-Spezies gehört zur Artengruppe tnit gelblicher Färbung, 12 Fühlergeißeln und langem Stiel der Cu-Gabel. Somit steht sie den paläarktischen Arten Cordyla flaviceps (STAEGER, 1840) und C. fasciata MEIGEN, 1830 äuBerst nahe. Die neue Monoclona-Spezies gehört zur Artengruppe mit ventral getrennten Gonocoxiten, wodurch sie in die Nähe von Monoclona silvatica ZAITZEV, 1983, M. orientalis ZAITZEV, 1983 und $M$. rufilatera (WALKER, 1837) zu stellen ist.

\section{Introduction}

Fungus gnats (Diptera: Sciaroidea: Mycetophilidae) of the Oriental region are still insufficiently known. According to COLLESS \& LIEPA (1973), only 122 species in 30 genera of the Mycetophilidae (s. str.) have been recorded from this region. A further 12 species and two genera were added by SASAKAWA (1979), SIVEC \& PLASSMANN (1982), CHANDLER (1991), BECHEV (1994, 1997), SøLI $(1995,1996)$ and KALLWEIT (1998).

I have had an opportunity to study a small but species-rich material of mycetophilids collected with a Malaise trap in Laos. Among other species, I found two apparently undescribed species of Cordyla MEIGEN, 1803 and Monoclona MIK, 1886. The genus Cordyla, so far known only from the Holarctic region, comprises 19 Palaearctic and 10 described Nearctic species, which have not been revised recently. The genus Monoclona occurs in the Holarctic and Neotropical regions. The Holarctic species were reviewed by ZAITZEV (1983). Five species were recognized in the Palaearctic region and 5 species in 
the Nearctic, of which Monoclona rufilatera (WALKER, 1837) and M. furcata JOHANNSEN, 1910 were proved to be Holarctic. There are also 5 species of Monoclona listed from the Neotropical region by PAPAVERO (1978).

Both new species are described and figured in this report, representing the first record of these genera from the Oriental region. The terminology used here principally follows SøLI (1997). The type specimens, including the cleared terminalia, are placed in the pinned microvials filled with glycerin.

\section{Systematic part}

\section{Cordyla orientalis sp. n.}

\section{Type material}

Holotype: LAOS south, Attapu Prov., Bolaven Plateau, $15 \mathrm{~km}$ SE of Ban Houaykong, Nong Lom lake env., $800 \mathrm{~m}, \mathrm{~N} 15^{\circ} 02^{\prime} \mathrm{E} 106^{\circ} 35^{\prime}$, edge of primary forest, 18. - 30.4.1999, 1 Y, E. JENDEK \& O. ŠAUŠA leg. (Malaise trap), deposited in the Silesian Museum, Opava (Czech Republic).

\section{Diagnostic characters}

A brownish yellow species with the base of the cubital fork well beyond that of the median, with 12 flagellomeres in male and the second palpomere comparatively long and light coloured. The male terminalia with ventral and dorsal lobes of gonostyli comparatively broad, rounded and densely covered with minute protuberances along their margins.

\section{Etymology}

The name refers to the occurrence of this species in the Oriental region.

\section{Description}

Male. Body length $2.85 \mathrm{~mm}$. General coloration yellowish, with brown markings on the abdomen.

Head. Yellowish brown. Antennae yellow, with 12 flagellomeres. Length of antenna 0.70 $\mathrm{mm}$, length of flagellum $0.48 \mathrm{~mm}$. Ratio of length to width for first flagellomere is 0.4 , that for the flagellomere 12 (apical) is 1.5. Mouthparts yellow. Palpi yellowish. Palpomere 2 swollen, somewhat darkened anteriorly, length $0.29 \mathrm{~mm}$, width $0.11 \mathrm{~mm}$. Relative lengths of palpomeres 2 to $4: 1.3: 1: 1$.

Thorax. Mesonotum yellowish brown, darker caudally, covered with dark setulae and with several setae dorsocentrally and along margins. Scutellum brown, with four long dark apical bristles, almost twice as long as scutellum. Mediotergite bare, yellowish brown. Laterotergite yellow, with about 10 setae medially. Anepimeron brownish yellow, with a blackish brown perpendicular spot anteriorly. Anepisternum covered with dark setulae and three setae at its posterior margin. Antepronotum and proepisternum with several setulae and about 10 dark setae. Halteres basally yellow, with brown knob.

Legs. All yellow. Coxae with 1-2 posterolateral setae near apex, hind coxa with 3 posterolateral setae basally. Fore femur subequal in length to fore coxa, mid and hind femora slightly longer. Fore tibia with apical spur reaching to about three fifths of the first 
tarsomere, mid tibia with anterior spur two times longer than the posterior one, hind spurs nearly subequal in length. Ratio of femur to tibia for particular legs: $2.0 ; 1.2 ; 1.1$. Ratio of tibia to tarsus: $0.3 ; 0.4 ; 0.6$. Ratio of first tarsomere to tarsus: $0.3 ; 0.4 ; 0.4$.

Wings. Hyaline. Wing length $1.72 \mathrm{~mm}$. Ratio of length to width 2.5 . Vein ta (= r-m) interrupted near its distal end. M2 not reaching to wing margin. Cubital fork short and widely open. Base of cubital fork well beyond the base of median fork. CuA1 downcurved. Ratio of ta to the stem of M: 0.43 . Ratio of the stem of $\mathrm{M}$ to the stem of Cu: 0.27 . Relative lengths of the stem of $M, M 1$ and M2: 1:3.8: 2.9. Relative lengths of the stem of $\mathrm{Cu}$, $\mathrm{CuA1}$ and CuA2: 1: 0.6:0.4.

Abdomen. Yellow. Tergites 1-3 with dark brown markings dorsally, tg 4-5 with dark transversal bands, tg 6 brown with yellow anterior margin. All tergites and most sternites (especially st 4) covered with dark setae.

\section{Terminalia}

(Fig. 1) Yellowish, caudally brown. Length of terminalia $0.31 \mathrm{~mm}$. Caudal margin of gonocoxites ventrally with wide rounded depression. Aedeagal complex nearly triangular
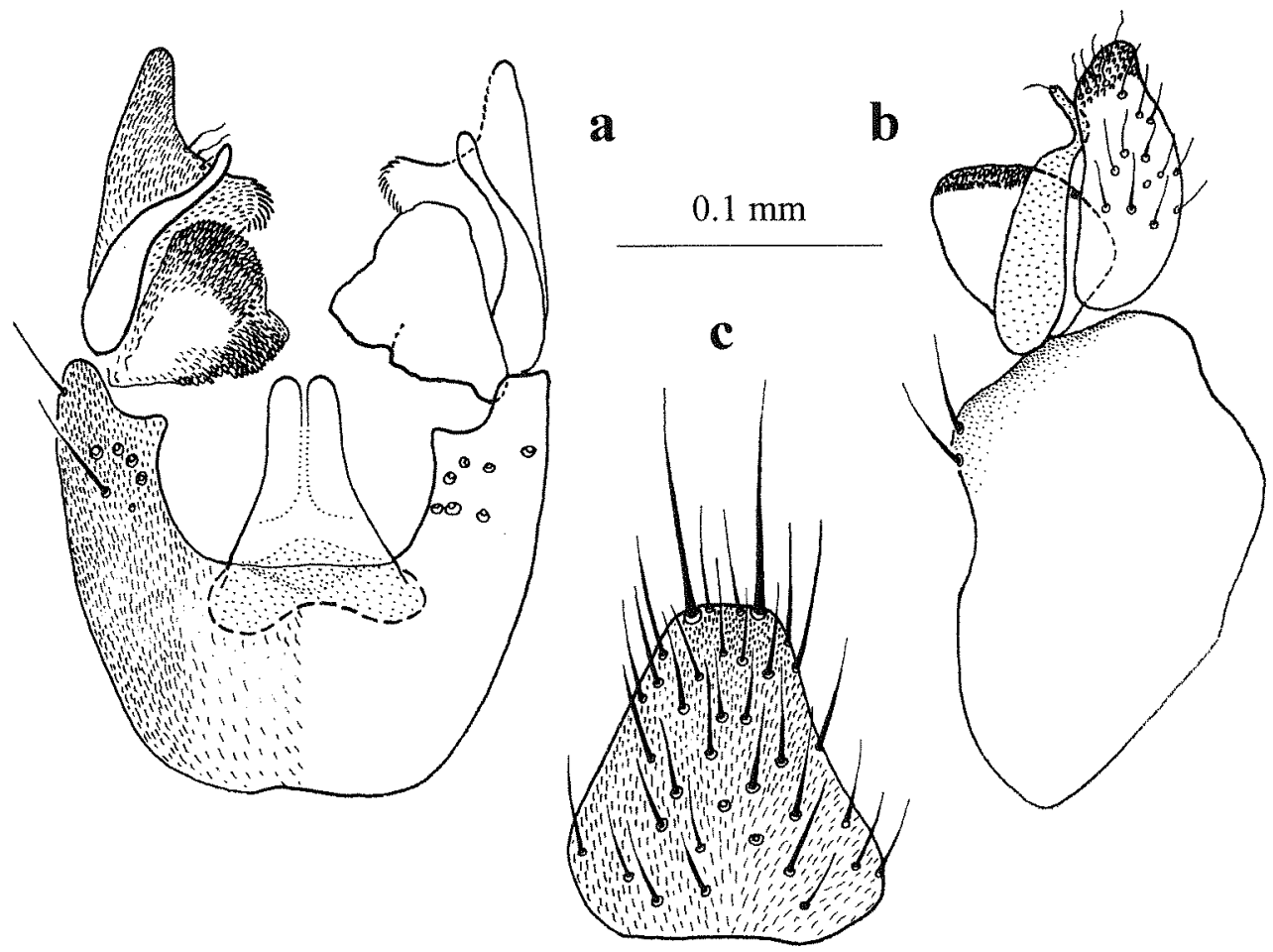

Fig. 1. Cordyla orientalis sp. n., male terminalia: a - ventral view, b-lateral view, c - sternite 8 . 
and rounded caudally (Fig. 1a). Gonostyli with three distinct lobes. Ventral lobe wide and rounded, with many minute protuberances along its margin, forming a dark apical band at lower magnification. Medial lobe narrow, slightly bent apically in lateral view (Fig. 1b). Dorsal lobe wide and bifid, covered with fine setulae. St 8 (Fig. 1c) subtriangular, with two long apical bristles.

Female. Unknown.

Biology. Unknown.

\section{Discussion}

As the revision of the genus Cordyla started by P. LAŠTOVKA many years ago still remains unpublished, there is little known about the relationships among particular species and many species, especially those from the Nearctic, are pootly known. The identification is based mainly on the morphology of the male terminalia, but the number of the flagellomeres, the shape and coloration of palpomere 2 and the wing venation are also very useful characters. The new species belongs to the species group with yellowish coloration, 12 flagellomeres and long stem of Cu-fork, and is thus most closely related to the Palaearctic Cordyla flaviceps (STAEGER, 1840) and C. fasciata MEIGEN, 1830.

\section{Monoclona laosilvatica sp. n.}

\section{Type material}

Holotype: LAOS south, Attapu Prov., Bolaven Plateau, $15 \mathrm{~km}$ SE of Ban Houaykong, Nong Lom lake env., $800 \mathrm{~m}, \mathrm{~N} 15^{\circ} 02^{\prime} \mathrm{E} 106^{\circ} 35^{\prime}$, edge of primary forest, 18.- 30.4.1999, 1 Y, E. JENDEK \& O. ŠAUŠA leg. (Malaise trap), deposited in the Silesian Museum, Opava (Czech Republic).

\section{Diagnostic characters}

Male terminalia with gonocoxites ventrally separated, long gonocoxal lobes and narrow gonostyli. Gonocoxal lobes densely covered with long setae and bearing a subapical processus. Internal processes of gonostyli with a long subapical seta.

\section{Etymology}

Derived from Laos, the country of the origin of the holotype, and silvatica, one of the closely related Palaearctic species.

\section{Description}

Male. Body length $4.25 \mathrm{~mm}$. General coloration yellowish brown.

Head. Yellow, with dark brown area around and behind ocelli. Antennae apically brown, scape and pedicel yellowish, flagellomeres 1-3 yellow and partially darkened. Length of flagellum $1.43 \mathrm{~mm}$. Ratio of length to width for first flagellomere is 1.6 , the other flagellomeres subequal in length, flagellomere 14 slightly longer. Lateral ocelli about twice as large as median and separated from the eye margin for a distance of about twice their diameter. Mouthparts yellow. Palpi yellowish, relative lengths of palpomeres 1.6:1:3:4.6.

Thorax. Mesonotum all yellow, densely covered with short darker setae and with 3 almost invisible brownish longitudinal stripes. Scutellum all yellow, with about 14 yellow apical bristles as long as scutellum, and about 10 shorter dark setae subapically. Anepisternum, anepimeron and preepisternum 2 yellow, without setae. Laterotergites yellow, 
with about 5-7 pale setae. Antepronotum and proepisternum yellow, with numerous setae. Metepisternum with 3-4 setae. Halteres basally yellow, with dark brown knob.

Legs. Yellow. Hind coxa with about 8 posterolateral setae. Fore tibia subequal in length to first tarsomere, with two short and one long apical spurs and 5 longer lateral setae. Mid tibia with two rows of 5 longer setae. Hind tibia with two rows of 7 setae. Tarsi yellow with numerous dark trichia and setae. Ratio of femur to tibia for particular legs: $1.0 ; 0.8 ; 0.7$. Ratio of tibia to tarsus: $0.5 ; 0.6 ; 1.0$.

Wings. Hyaline, covered with both microtrichia and macrotrichia. Macrotrichia directed proximally. Wing length $3.15 \mathrm{~mm}$. Ratio of length to width 2.5 . Length of Sc $1.4 \mathrm{~mm}$. Sc2 located proximally to Rs. R4 present. M-petiole about twice as short as ta (= r-m). $\mathrm{CuA}$ slightly divergent with M2. Anal veins not traceable.

Abdomen. Yellow. Tergites 3-5 with broad dark brown bands, not reaching to anterior, posterior and lateral margins of tergites. All tergites covered with dark setae.

\section{Terminalia}

(Fig. 2) Blackish brown. Length of terminalia $0.75 \mathrm{~mm}$. Gonostyli narrow, shorter than gonocoxites. Internal processus of a gonostylus simple, almost straight, bearing two setae, the subapical one being longer and more conspicuous, and a dark apical tooth (Fig. 2c). Aedeagus nearly A-shaped, slightly narrowing, with three darker projections at the apex. Gonocoxites basally separated, ventral gonocoxal lobes very long, densely

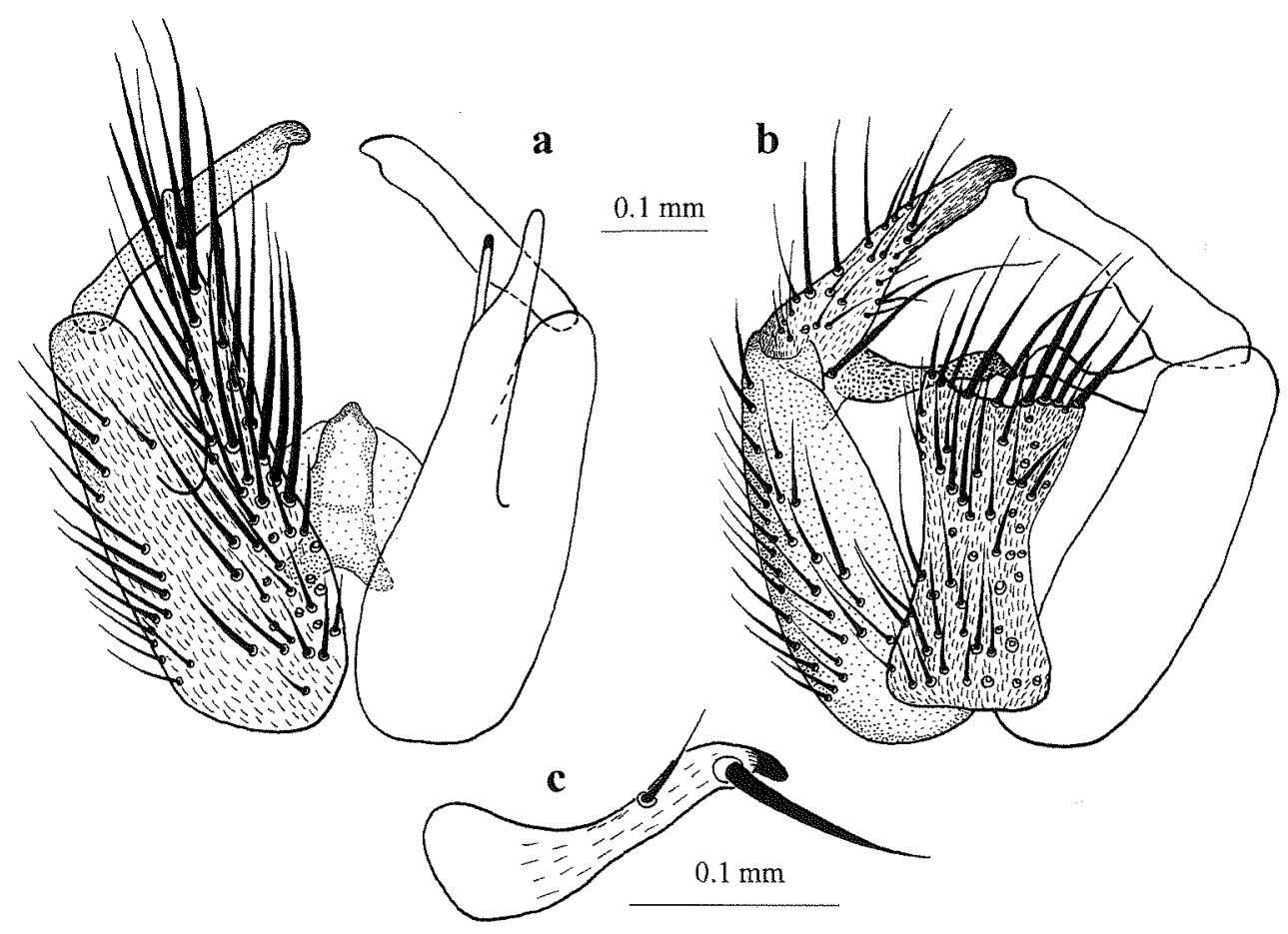

Fig. 2. Monoclona laosibuatica sp. n., male terminalia: a - ventral view, b - dorsal view, $\mathbf{c}$ - internal processus of a gonostylus. 
covered with long setae overlapping a subapical parallel processus on each lobe. Tergite 9 almost as long as gonocoxites, medially narrowed, covered with long setae.

Female. Unknown.

Biology. Unknown.

\section{Discussion}

Most species of Monoclona have rather uniform coloration and other somatic characters, and the identification is based primarily on the morphology of the male terminalia, which are very characteristic for a particular species. The new species belongs to the species group with ventrally separated gonocoxites and is closely related to Monoclona silvatica ZAITZEV, 1983, M. orientalis ZAITZEV, 1983 and M. rufilatera (WALKER, 1837), from which it can be easily separated by the above mentioned combination of characters on the male terminalia.

\section{Acknowledgements}

I am grateful to my Slovak colleagues E. JENDEK and O. ŠAUŠA (both Bratislava, Slovakia) for providing me with their mycetophilid material from Laos and to M. KOZÁNEK and L. ROLLER for the hospitality during my visit in Bratislava. Mr. P. J. CHANDLER (Slough, England) is thanked for the improvement of the English presentation of this paper.

\section{References}

BECHEV, D. 1994: Three genera of Mycetophilidae new to the fauna of Sumatra and Jara, with description of Zygomyia polyspina spec. nov. (Insecta: Diptera), - Reichenbachia Mus. Tierkd. Dresden 30: 191-192.

BECHEV, D. 1997: The genus Sceptonia WINNERTZ in the Oriental region. - Spixiana 20: 181-182.

CHANDLER, P. J. 1991: New species and additions to the British list of the fungus gnat genera Zygomyia WinnerTZ and Sceptonia WinNerTZ (Diptera, Mycetophilidae). - Br. J. Ent. Nat. Hist. 4: 143-155.

COLLES, D. H. \& LIEPA Z. 1973: Superfamily Mycetophiloidea. Family Mycetophilidae (Fungivoridae). Pp. 444-463 - In: DELFINADO \& HARDY (Eds): A catalog of the Diptera of the Oriental region. Vol. 1.: 618 pp. Honolulu.

KALlwEIT, U. 1998: Notes on the genus Metanepsia EDwARDS and its relatives from East Asia (Insecta: Diptera: Mycetophilidae). - Reichenbachia Mus. Tierkd. Dresden 32: 341-353.

PAPAvero, N. 1978: Family Mycetophilidae (Fungivoridae). A catalogue of the Diptera of the Americas south of the United States. 19 E. - 78 pp. Sao Paulo.

SASAKAWA, M. 1979: A new mushroom pest from Thailand (Diptera: Mycetophilidae). - Akitu 28: 1-4.

StVEC, I. \& PLASSMANN, E. 1982: Sechs neue Pilzmücken aus Sri Lanka. - Spixiana 5: 7-13.

Søl, G. E. E. 1995: Sciopbila MEIGEN, 1818 from the Oriental tegion (Diptera, Mycetophilidae). -Tijdschrift voor Entomologie 138: 283-289.

SøLI, G. E. E. 1996: Chalastonepsia orientalis gen. n., sp. n., a second genus in the tribe Metanepsini (Diptera, Mycetophilidae). - Tijdschrift voor Entomologie 139: 79-83.

SøŁ, G. E. E. 1997: The adult morphology of Mycetophilidae (s. str.), with a tentative phylogeny of the family (Diptera, Sciaroidea). - Ent. scand. Suppl. 50: 5-55.

ZAITZEV, A. I. 1983: A review of Holarctic species of the genus Monoilona MIK (Diptera, Mycetophilidae). Entomologicheskoye Obozreniye 62: 620-627. [In Russian.]

\section{Author's address:}

JAN ŠEVČ́K

Horymírova 2912/104

CZ-700 30 Ostrava 30

Czech Republic 